\title{
THINKING ABOUT THE FUTURE: PHILOSOPHY AND SCIENCE FICTION IN CLAIRE NORTH'S NOVEL "THE FIRST FIFTEEN LIVES OF HARRY AUGUST"
}

As developed in this paper, science fiction shows us the distorted vision of the present with its anxieties about (mis) use of science although it deals mostly with the future and alternative realities. Thus SF stories both praise scientific progress and repulse its terrible applications caused by irresponsible abuse of technology. This paper

focuses on how contemporary SF deals with philosophical issues of life, death, technology, and the role of

science in society. It reviews Claire North's novel "The First Fifteen Lives of Harry August" in which SF conventions parallel and intensify the thriller narrative. The philosophies of Nietzsche and Heidegger have been

employed to discuss the theory of eternal return and related topics of nihilism, devaluation of values, and purpose of existence. It is stated that the novel reveals how cognition of totality may lead to death and illustrates that human beings are incapable of achieving omniscience. Personal time is measured by memory and is always linear; therefore it can guarantee meaningful existence only when its arrow points towards growth and maturity.

It is shown that ethical issues raised in the novel are based on the distinction between theoretical science signifying truth and its practical application meaning power. Knowledge by itself lies beyond morality; however, means used in its pursuit entail responsibility to others.

Key words: responsible creativity, moral obligations, eternal return, nihilism, linear time, omniscience.

Introduction. Philosophical perspective is unavoidable in all genres and modes of literature, and science fiction (SF) is the one that deals mostly with normative questions. Some stories of SF focus on the potential of learning and research; many more SF works examine how far humanity can go in their pursuit of knowledge and where this journey may lead them. Contemporary British writer Claire North employs SF conventions in her novel "The First Fifteen Lives of Harry August" (2014) to rethink the issue of responsible and timely creativity. She implies that persons who (mis)use science pose a bigger threat than science itself.

Claire North's novel was well received by critics and audience who praised its masterful blend of literary and genre fiction, clever plot twists [1; 2], deep elaboration of philosophy of the meaning of life, and the nature of time and selfhood [3], but disapproved of overly fragmented structure and "info-dump" [4]. However, these reviews failed to present an overall analysis of the problems outlined.

Scope. Our paper is aimed to fill this gap and elaborate on the complex relation of the novel's SF mode with the issues of life, death, time and technology. We will also analyse how moral imperatives concerning the future are entwined with the narrative.

Discussion. SF stories rethink the present and step into the realm of "what-if" thus becoming "thought experiments about anything we can imagine, from global warming to evolution" [5: 41]. The narratives, removed from a conventional reality, model the invented "spaces of liberty" (Augusto Boal) as well as the macabre dystopian and post-apocalyptic images of what our future can be and how freedom can be compromised by misuse of technology. Despite its concern with futural thinking and what-if scenarios, SF analyses the values of the present and "stipulate[s] how forces work to define humanity" [5: 78].

Claire North's novel belongs to the "soft" SF tradition, which is "more character driven and more concerned with the social and political ramifications of technological developments than with the technologies themselves" [5:25]. Despite its complicated composition, the novel has a recognisable thriller plot. The protagonist and narrator, Harry August, born on New Year's Day 1919, lives in a universe in which the whole existence recurs again and again in the same form with an established set of unchangeable events (e.g. invention of a nuclear bomb, meltdown of reactor four, 9 / 11 etc.). He belongs to a special kind of humans, known as kalachakra or ouroboran, who are aware of the fact that they relive their lives many times and their death subsequently leads to rebirth (if their life is not terminated prenatally). Their knowledge of such repetition is both their blessing, because they can avoid mistakes of a previous life and start everything anew, and their curse, because sooner or later the burden of memories leads to boredom and apathy. Kalachakra are trapped in a particular spatialtemporal segment limited by their birth, which is a fixed point and thus unchangeable, and death, which, if not violent, is nearly always the same (usually some fatal illness). In his eleventh life Harry receives a warning, sent back through time by the future generations of Cronus Club, the kalachakra's organisation, that the world is ending and the end is coming faster than before. Harry is bored and longing for adventure, so he answers the call and starts his investigation. He finds out that the disruption of the future may be caused by his once friend and rival Vincent Rankis, who is building a quantum mirror, a device that can disclose all mysteries of the universe and allows people to "[1]ook at all things, with the eyes of God" (Ch. 65) [6]. Harry is seduced by the idea of 
finding the theory of everything, therefore he joins the enterprise, although the machine may break the established timeline and kill the future life. However, Vincent turns out to be ruthless, merciless and murderous. He tortures Harry and tries to wipe out his memories (unsuccessfully) after Harry refuses to continue his work. Harry, reborn with his memories unharmed, spends his following three lives tracking, hunting, and finally nailing Vincent and destroying the quantum mirror.

The main characters' arcs are built upon their search for the meaning and purpose of existence. Kalachakra live in the endlessly repetitive segment of the present. Every change made by them exists only in one world; after death, when the universe is reset, kalachakra pop into just another world with their previous traces erased. For them the future is merely an illusion they are never allowed seeing, although they can learn about it from the whispers sent back from the centuries to come. This universe makes the issue of meaning a little bit complicated. From one hand, kalachakra can influence only one timeline so their deeds do not have any consequences on a grand scale and the world recovers afterwards. They can change only the lives (or deaths) of their own kin. From the other hand, they have to live with their sorrow, remorse, and emotional baggage much longer. In any case, the majority of the Cronus Club members choose to unofficially dissociate themselves from the rest of the world and mind their own business. They usually make profit from their knowledge (recollection, to be precise) of the events to achieve some comfort and wealth as well as to finance the childhood benevolent fund to support the newly re-born members.

North's universe with its eternal return is a metaphor of nihilism and life lacking significance and values. The kalachakra who can remember their previous lives are mentally trapped in the recurrence of events - they see their achievements decayed and their lives deteriorated to the very beginning so they end up disappointed and bored. In such a world the idea of progress is a delusion and growth becomes useless because each turn cancels all previous developments. As Harry points out, "... after the first few centuries, most kalachakra reached a plateau where time hardly mattered and the soul barely changed" (Ch. 31) [6]. This invariability equals inner death where nothing is new and a person bears the burden of memories.

The theory of Eternal Return comes from ancient philosophy based on natural circles. It declined in the West after Christianity introduced the opposite notion of linear time. In the $19^{\text {th }}$ century it was revived in the works of such thinkers as Spengler and Toynbee, who rejected the endless progress of human civilization, and Nietzsche, who expressed the sense of pointless universe. In order to overcome and accept nihilism, Nietzsche introduced the concept of Übermensch "to affirm the view that humanity alone must remake itself according to the measure it chooses, and thus to impose itself upon things" [7: 29]. In the $20^{\text {th }}$ century a comprehensive analysis of nihilism was made by Heidegger. He pointed out that Nietzsche's super-man was not a solution for nihilism but the product of it. For Heidegger, contemporary nihilism originated in productionist metaphysics and exploitative thinking that "renders explicit the destructive tendency of Western thought to conceive the world merely in terms that serve to enhance the apparent power and mastery of the thinker" [7: 29]. Hence, nihilism emerges when a person searching for certainty in the world uses knowledge as the means of "being-above", "mastering" and domineering objects.

In her novel North distinguishes knowledge as truth (theoretical science) and knowledge as power (misuses and abuses of science). Two described cataclysms, which led to the disruption of history and death of many generations of kalachakra, are caused by improper time shift in scientific progress. Both Victor Hoeness, who tried to bring peace by uniting the world under one ruler, and Vincent Rankis, who wanted to find the theory of everything, used the knowledge of the future and introduced the advanced technology ahead of their time without consideration for the consequences of their actions. Technology is regarded as synonym for time itself and the artificial acceleration of its development creates a situation of future without future: "Technology had changed - time had changed - and many of us simply were not born. We haven't heard from the twenty second century at all. We have no idea what happened to them" (Ch. 76) [6]. In the novel historian Victor Hoeness personifies the totalitarian idea that peace and stability can be achieved by subjugation while physicist Vincent Rankis represents the utilitarian thinking of a global techno-scientific civilization that regards people merely as expendables or means to achieve a result. He doesn't think in terms of good or evil, but only in terms of efficiency: "The question you must ask yourself is this: will the good you do the other man ... exceed the harm, exhaustion and general sense of distaste that you incur to yourself in helping him? I know it doesn't sound very noble, Harry, but ... frankly everyone ends up a worse mess than they were to begin with" (Ch. 37) [6]. Even though both men seem to act with good intentions in heart (eternal peace or omniscience and omnipotence for the human race), they lack benevolence and compassion, so that the noble cause they are fanatically devoted to is compromised by the means they apply and effects they neglect. Another reason is incompleteness of their knowledge and impossibility to grasp the totality of the universe.

Vincent's plan to build a quantum mirror is an instant of a godless universe. Endless repetition of lives and inability to change the course of history make kalachakra turn to science for an explanation after religion and philosophy fail to provide them with one. Vincent replaces god with the machine that fills his life with meaning: "We're making something bigger. We're making something better. We're making... a kind of god, I suppose. Yes, I think that's what we are doing, in fact. A kind of deity" (Ch. 65) [6]. However, science is not omnipotent and 
shouldn't be substituted for religion, philosophy or ethics. By definition, science is a complex social activity, conducted based on generally accepted ethical principles; it is a blend of logic and imagination and cannot provide complete answers to all questions; moreover, scientists participate in public affairs as both specialists and citizens [5: 41]. Science is merely another product of human civilization that doesn't guarantee omnipotence. Vincent builds the quantum mirror to comprehend the universe as a whole so that he could disrupt the endless repetition and fill his life with meaning. However, it is his indifference to others that makes him an evildoer. He doesn't consider the consequences of his actions and thus denies his responsibility for application of his creation.

The end of time as well as its constant delay is an inevitable part of eschatological thinking, i.e. people know that there will be an end but they hope it won't be in their lifetime. When Vincent Rankis draws this postponed unidentifiable future to the present he threatens to wipe it out entirely. The prolonged period of anticipation is replaced by a moment of destructive experience. This act of observing the totality in a single instance that would simultaneously destroy the universe is a simulation of death in order to achieve the completion of being. However, Vincent's plan is not suicidal - it is completely murderous since it ignores the lives of others. It not only wipes out the future of a world where the machine is to be activated but it is also capable of destroying the whole reality. Vincent is beckoned by the ultimate knowledge that can be achieved only by death - not a death that means starting a new life for kalachakra, but the death that he is deprived of. Only the final death brings, in Heidegger's terms, "a disposition to the naked being-in-the-world, to pure Dasein" and gives a person "a superlative possibility" to face the totality of life and embrace the whole life in a single moment: "The being that I will be in the 'last' of my Dasein, that I can be at any moment, this possibility is that of my own most 'I am,' which means that I will be my own most I. <..> For I myself am this constant and utmost possibility of myself, namely, to be no more." [8:291, 313]. It is the anticipation and fear of death that spices life; being unaware of when the end comes may become a remedy for the overly bored members of the Cronus Club. North's character Fidel Gussman chooses such an unpredictable life battling (and dying in various and unexpected ways) at any war he could take part during his lifespan: "You're born knowing everything that's gonna happen in your lifetime, every fucking bit of it, and you're like 'Let's just watch'? Screw that - let's get out there, let's live a little, get surprised! <..> I'm feeling on top of the world, I mean like, knowing every second could be my last, it's this buzz, this amazing buzz" (Ch. 50) [6].

Kalachakra can achieve "real" death in one of two ways. The first death is the elimination of self. It is achieved after a person undergoes the Forgetting, a procedure that wipes out their mind and memory. In this case kalachakra are born again without the baggage of grief and sins of the past and start a new life with the same initial conditions (place and time of birth; social and cultural environment). Those former selves are distinguished from the new ones and are regarded as different persons. That is why Akinleye talks about her former self as "she": "But I tell myself it is not me they have known - it is the last me, the old me, the me that I have forgotten" (Ch. 64) [6]. This is an example of the two concepts of identity distinguished by John Locke. He defined a concept based on bodily continuity as "man" and a forensic concept, having to do with memory and responsibility, as "person". That is why in accordance with Christian thought "[t]here will be a resurrection of the body, so that the same man (that is, the same bodily man or woman) will be found in the hereafter. However, the reward or punishment is prepared for the same person" [9: 146-147]. The death by the Forgetting releases kalachakra from responsibility for crimes or sins because the previous self is wiped out despite the fact that the new one shares the same body. As Virginia notes, it is "[a] clean slate, a chance to be pure and innocent again" (Ch. 26) [6]. The Forgetting erases memories and knowledge while some personality traits remain, as exampled by Akinleye (who dedicated her new life to caring for others as enthusiastically as she did to sinful pleasures of the body in her past one) or Virginia (who was forced to forget twice as a punishment for her wrongdoing and crimes against her kind).

The second death for kalachakra is the total destruction of both mind and body by abortion. If ouroborans are not born once they do not return to the next life. They just cease to exist and are wiped from the history. The procedure of abortion is a great sin against kalachakra; however, it may be carried out officially to execute those, like Victor Hoeness, who committed terrible crimes. Harry is determined to use it on Vincent Rankis to punish him for murdering kalachakra and also to prevent him from activating the quantum mirror and ruining the conventional future. As Heidegger puts it, Dasein is always incomplete and lacks something; but one reaches wholeness in death which is always a personal death and not someone else's death or death in general. For kalachakra, death-before-rebirth does not guarantee a superlative experience because it is not final. It is just a failure of a body followed by a few annoying years of childhood before the Club comes to reclaim its member. Such a death does not carry any sense for the world and ouroborans because consequent birth transports them to a reset universe where all previous achievements are cancelled and exist only in the person's memory. The absence of results decreases the significance and meaning of life itself: "All this ... when we are dead, will no longer be. Will not have been. Loved ones we have watched die will be born again and we will remember that they were loved, but they will not know us, and none of this will matter. Not the men who lived or the men who died. Only the ideas and memories they made" (Ch. 52) [6]. Human consciousness, as well as the whole human culture, is based on what Ian Hacking calls a "memory-thinking": personal memory defines the individual self 
while communal memory plays a major role in group identity [9: 210]. For kalachakra, the totality of recollections not only shapes the self ("we were simply the sum of our memories" (Ch. 76) [6]) but also becomes the most valuable thing in life while the Forgetting is the wipe-out of a person ("A loss of time, experience, knowledge - a loss of all the things that had made this man who he had been" (Ch. 62) [6]). Moreover, memory serves as the only proof of their previous existence in the reset universe since the past leaves no material traces. The remembrance defines the reality and measures time. As Harry says, "... I'd died and that world, to me, might never been if memory didn't make it so" (Ch. 55) [6]. Through memory the time itself is perceived because it is neither material nor objective. It is merely an observation of change based on our recollection that a thing in not the same as we remember it to be.

The excess of memory has a devastating effect on personality since mind does not have a capacity to contain the experience gained. In psychology the state of the memory excess is called hypermnesia; it is usually caused by traumatic events and was once thought to be pathological. Memory becomes the repository for trauma - "a wound to the soul", and changes in memory lead to "significant alterations in the sense of self" [9: 87]. As Virginia says, "And one day you might want $<\ldots>$ to forget. The mind struggles to re-create the joy of a first kiss, but somehow manages to recall the terror of pain, the flush of humiliation and the burden of guilt with a startling clarity" (Ch. 26) [6]. According to contemporary psychology, ordinary memories differ from traumatic ones. Along with propositional memory, when "the brain virtually never represses the memory of a profoundly important event and then reproduces it later, accurately", there exists "another kind of memory, which expresses itself not in sentences but in scenes that come whole to a trauma victim, flashbacks constituted by feelings and images" [9: 125]. Memory as knowledge and life experience, from one hand, puts an ouroboran on a higher level compared to others; from another hand, memory, regarded as a criterion of personal identity, becomes a realm of entrapment and a burden one has to carry until it becomes too hard to bear.

The problem of being lost in recollections is different for Harry who is a mnemonic, a kalachakra who has a unique ability to remember everything in details. His traumatic experience is more painful because he can recall all misfortunes of his previous lives and he cannot forget. That is why the past becomes the dead weight over his soul dominating over his mind and obscuring his futural thinking ("I know now that there is something dead inside me though I cannot remember exactly when it died" (Ch. 72) [6]). When this burden of perfect memory becomes too much to bear it awakens Harry and triggers his actions. As he recalls all tortures Vincent used on him Harry cries for vengeance: "Centuries are a long time to hold a grudge, but then... / Remember / Remember like a mnemonic, and here we are again... I close my eyes and I remember and yes. / It is vengeance. / And perhaps a very small realisation that something inside me has died and that this is the only way I can think of to get it back. A notion of 'doing the right thing' - as if that meant anything to me any more" (Ch. 81) [6]. Memory equals self-knowledge and awareness of one's own virtues and vices. It allows a person to understand the past and the present but nevertheless accept one's good and bad traits and grow into a better and mature self. Vincent fails to admit to himself that the quantum mirror is not a way out of the eternal return. He believes that "this is what will make gods, give us the vision of the creator; this research could unlock infinity" (Ch. 52) [6]. He substitutes the meaning of existence with another trap of obsession that drags him deeper and deeper into the vortex of recurrence demanding more and more lifespans to sacrifice ("Dozens of lives, centuries of my life, from the first stirring of consciousness in my father's arms to the day I die, this, Harry, this is my purpose" (Ch. 52) [6]). Harry, on the contrary, escapes the trap of endless and meaningless repetition of his previous being. The novel mentions that once a mnemonic Koch said that there were only two ways left to kalachakra, namely "either seek to change the world, or become brutal arbitrators of our own kind" (Ch. 27) [6], leaving no place for remorse or forgiveness in the heart. Harry cannot erase his recollections but comes to terms with his past and opens himself to the future. He chooses the third way not known for kalachakra before; he chooses to protect the world from his kin but keep his humanity and feelings. He manages to embrace existence as a whole and accept its ways and his role in it. He is merely a human being who cannot and shouldn't challenge the course of history; even his obligation to abort Vincent in the next life in order to protect the world form destruction does not mean that he is to become a heartless monster: "I am writing this for you. / My enemy. / My friend. $<\ldots>$ This is my ... confession, if you will. My victory, my apology. <..> And all will be as it should. / Time will continue. / The Clubs will spread their fingers across the aeons, and nothing will change. / We will not be gods, you or I. / We will not look into that mirror. / Instead, for those few days you have left, you are mortal at last" (Ch. 82) [6]. Consequently Harry sees the way to avoid returning into the previous state over and over again in the eternally recurrent universe. He finds hope to leave a trace in the world and his linear time is now defined by the idea of growing and maturing that means taking responsibility for one's actions and living towards and for the future one cannot reach.

Conclusions. In her novel "The First Fifteen Lives of Harry August", Claire North uses SF conventions to reinforce the thriller narrative and construct the potential future and alternative reality to highlight the extremes and perversions of the present in terms of application of science and technology. She notes that distinction between good and harmful knowledge lies in a person responsible for its application thus linking knowledge used for dominance with nihilistic exploitative thinking. North denies the idea of objectively meaningless 
universe and suggests that purpose of life is a subjective construct. Since time is measured by memories, life equals personal experience and its significance is defined by moral values. Personal time is always linear and its arrow points towards growth and maturity. This idea entails responsibility to the future as well as appreciation of the present. The metaphor of the rip of time and the collapse of reality signifies a society that ceases to function in a proper way when individuals from one generation (or time period) fail to fulfil their obligations to the future. The present paper has discussed only several aspects of Claire North's novel; nevertheless we believe our work could be the basis for further investigations and a close reading of the novel could demonstrate how the text was influenced by the contemporary scientific discourse.

\section{REFERENCES}

1. The First Fifteen Lives of Harry August by Claire North (now in pbk) [Electronic resource]/ Reviewed by Harriet Devine // Shiny New Books. - Access mode : http://shinynewbooks.co.uk/shiny-new-books-archive/issue-2archive/fiction02/the-first-fifteen-lives-of-harry-august-by-claire-north.

2. The First Fifteen Lives of Harry August. Discussion Guide [Electronic resource] // Book Discussions. - Access mode : http://groupreads.blogspot.com/2016/02/the-first-fifteen-lives-of-harry-august.html?m=1.

3. Anders Ch. J. First Fifteen Lives of Harry August is a Masterful Literary Thriller [Electronic resource] / Charlie Jane Anders // io9 Book review. - Access mode : http://www.google.com/amp/s/io9.gizmodo.com/firstfifteen-lives-of-harry-august-is-a-masterful-lite-1562310481/amp.

4. Book Review : The First Fifteen lives of Harry August by Claire North [Electronic resource] / Posted by Mondyboy // The Hysterical Hamster. - Access mode : http://mondyboy.com/?p=7442.

5. Science Fiction and Speculative Fiction : Challenging Genres / Edited by P. L. Thomas. - Rotterdam ; Boston; Taipei: Sense Publishers, 2013. - viii+220 p.

6. North C. The First Fifteen Lives of Harry August [epub] / Claire North. - New York : Redhook Books, 2014. Access mode : http://ebookmall.com/ebook/the-first-fifteen-lives-of-harry-august/claire-north/9780316399630.

7. Clark T. Martin Heidegger / Timothy Clark. - New York, NY : Routledge, 2002. $-\mathrm{xvi+184} \mathrm{p.}$

8. Heidegger M. History of the Concept of Time. Prolegomena / Translated by Theodore Kisiel. - Bloomington : Indiana University Press, 1985. - xix +329 p.

9. Hacking I. Rewriting the Soul : Multiple Personality and the Sciences of Memory / Ian Hacking. - Princeton, New Jersey : Princeton University Press, 1995. - x+336 p.

\section{Федосова М. О. Думаючи про майбутнє: філософія і наукова фантастика в романі Клер Норт "Периі п'ятнадцять життів Гаррі Огеста".}

У статті розглянуто філософські засади роману Клер Норт "Перші п'ятнадиять життів Гаррі Огеста". Проаналізовано авторські конщепиії життя, смерті, сенсу існування, а також ставлення до науки та ї̈ ролі в суспільстві. Визначено, щчо письменниця використовує традицї̈ наукової фантастики, щчоб протиставити особистий лінійний час онтологічній циклічності. Ця опозиція покладена в основу етики роману, що наголошує на моральному приниипі відповідальності за практичне застосування

наукових досліджень і нагадує про важливість не шкодити іншим під час впровадження нових технологій.

Ключові слова: відповідальне творення, моральні зобов'язання, вічне повернення, нігілізм, лінійний час, всевідання.

\section{Федосова М. А. Думая о будущем: философия и научная фантастика в романе Клэр Норт "Первые пятнадцать жизней Гарри Огеста".}

В статье рассмотрены философские основы романа Клэр Норт "Первые пятнадиать жизней Гарри Огеста". Проанализировань авторские концееции жизни, смерти, смысла существования, а такље отношение к науке и ее роли в обществе. Определено, что писательница использует традиции научной фантастики, чтобы противопоставить личное линейное время онтологической цииклчности. Данная оппозиция лежит в основе этики романа, который подчеркивает моральный принции ответственности за практическое применение научных исследований и напоминает о важности не вредить другим при внедрении новых технологий.

Ключевые слова: ответственное творение, моральные обязанности, вечное возвращение, нигилизм, линейное время, всезнание. 